INEEL/CON-99-00711
PREPRINT
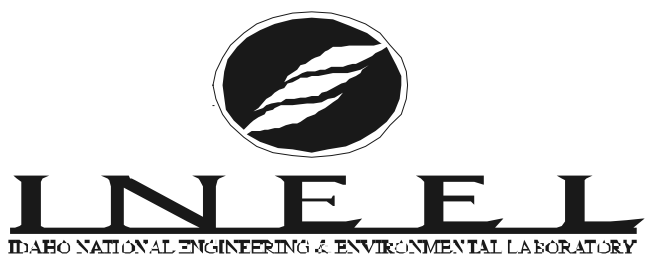

Safety Analyses at the Idaho National
Engineering and Environmental Laboratory Test
Reactor Area - Past to Present

R. G. Ambrosek

F. W. Ingram

November 14, 1999
This is a preprint of a paper intended for publication in a journal or proceedings. Since changes may be made before publication, this preprint should not be cited or reproduced without permission of the author.

This document was prepared as a account of work sponsored by an agency of the United States Government. Neither the United States Government nor any agency thereof, or any of their employees, makes any warranty, expressed or implied, or assumes any legal liability or responsibility for any third party's use, or the results of such use, of any information, apparatus, product or process disclosed in this report, or represents that its use by such third party would not infringe privately owned rights. The views expressed in this paper are not necessarily those of the U.S. Government or the sponsoring agency. 


\title{
SAFETY ANALYSES AT THE IDAHO NATIONAL ENGINEERING AND ENVIRONMENTAL LABORATORY TEST REACTOR AREA -- PAST TO PRESENT
}

\author{
Richard G. Ambrosek Fred W. Ingram \\ Lockheed Martin Idaho Technologies Company \\ P. O. Box 1625 MS 3885 \\ Idaho Falls, Idaho 83415-3885 \\ (208) 526-7710 Voice (208) 526-6971 Fax rga@inel.gov
}

\begin{abstract}
Test reactors are unique in that the core configuration may change with each operating interval. The process of safety analyses for test reactors at the Idaho National Engineering and Environmental Test Reactor Area has evolved as the computing capabilities, software, and regulatory requirements have changed. The evaluations for experiments and the reactor have moved from measurements in a set configuration and then application to other configurations with a relatively large error to modeling in three-dimensions and explicit analyses for each experiment and operating interval. This evolution is briefly discussed for the Test Reactor Area.
\end{abstract}

\section{INTRODUCTION}

There have been three test reactors built at the Test Reactor Area located in the Idaho National Engineering and Environmental Laboratory. They were the Materials Testing Reactor (MTR), the Engineering Test Reactor (ETR), and the Advanced Test Reactor (ATR). A unique feature of test reactors is the variability of the core configuration and the experiment loading in the core and reflector test positions. Due to this variability the safety of each operating interval must be evaluated and shown to be acceptable for operation. The method for demonstrating this acceptability has changed over the years and the tools available for the analyses have also changed.

Initially most of the evaluations for the MTR were performed with mechanical calculators, slide rules, and pencil. Then some computers were built. These were large and slow. Many times a large portion of a day or days was required for an evaluation and the computer would fill a whole building. The computers advanced in speed and codes were written specific to the computer system in many instances. This resulted in an increase in computing speed, but the systems were still large. Some of the systems utilized were built by IBM, VAX, CDC, and CRAY. Currently most of the evaluations are performed with workstations, most of which will sit in a small office space. The speed of calculation is very fast and large

Large advancements in methodology and accuracy of the heat transfer evaluations has also occurred. Early evaluations used a "hot spot", "hot channel" approach. The variables thought to be important to the heat flux magnitude were identified, and the variation in this parameter that was deemed applicable was then noted. This resulted in a multiplier on the parameter. These multiplication variances were then combined as a product. This product became the "hot spot", simulations can be performed in minutes when hours or days were previously required.

Initial safety evaluations were by necessity rather rudimentary. The process involved solution of equations from experimental correlations. The data sources were few in number and the direct applicability was small. The nuclear industry was an infant. There were some heat transfer data available from other industries, such as manufacturing and power (steam). Most of the nuclear physics parameters were obtained by experimental studies in critical facilities. As the nuclear industry advanced there were many heat transfer studies completed with various operating conditions, materials and configurations. Codes were developed for core physics evaluations. In most cases due to the complexity of the experimental facilities there were simplifications to allow construction of one- or twodimensional models. As the industry matured the use of threedimensional models became available. The advances in computing capability allowed more detail in modeling and currently large threedimensional models are constructed. In some cases the neutronics are evaluated by tracking each particle generated in the fission process until it is absorbed or lost outside of the confining boundary.

Initially the safety margins for the neutronic parameter of greatest interest, the criticality, was evaluated by critical facility measurements and adjustment of the fuel loading until the proper critical position was obtained. As the data base increased the data was fit parametrically and small programs developed. Changes in experimental loadings and the influence on other positions were generally ignored. If the experimenter required flux wire measurements could be performed. However, there was a large uncertainty due to the counting capabilities and the restrictions on placement directly in the experiments. Today the facilities can be modeled in detail and the excess reactivity in a configuration predicted with very good accuracy. The influence on flux levels and spectrum can be evaluated for each change in configuration if required.

factor, and the heat flux multiplied by the "hot spot" factor had to remain below the critical heat flux. The process was repeated for those parameters which would influence the enthalpy rise in the coolant channel. The product of the factors then became the "hot channel" multiplier. The rise in temperature times the "hot cannel" factor added to the inlet temperature was required to be less than the saturation temperature. Advances in computer capability, correlation 
accuracy, and innovations in mathematical techniques led to a statistical evaluation. In this process each of the identified variables were combined statistically and the required safety margin was a number of standard deviations from the calculated critical heat flux or flow instability temperature.

Advances in computing capability and development of system codes have resulted in evaluations for loss of coolant events and establishment of specific melt and release limits. Original evaluations bounded the consequences of these accidents by evaluation of total melt.

\section{NEUTRONIC ANALYSIS}

\section{A. Design Evaluations}

The initial evaluations for reactivity additions in the ATR were performed using analog techniques. The calculations incorporated only the flux level scram safety action and the effects of the negative temperature coefficient. The reactivity insertion values were obtained by experimental measurements in the ATR Critical Facility (ATRC).

Measurements in the ATRC showed that voiding a flux trap and experiment resulted in the maximum accident consequences for a reactivity insertion. The evaluations showed a peak reactor power greater than 10 times normal with an integrated energy of $130 \mathrm{MW}$ $\sec ^{(1)}$. The results are shown in Figure 1.

Based on SPERT ${ }^{(2)}$ and BORAX ${ }^{(3)}$ transient data, the energy deposition between the fuel and coolant was estimated as 50-50. This resulted in an energy addition of $\sim 65 \mathrm{MW}$-sec in the fuel. Evaluations predicted that fuel plate melting would occur at the hot spot with $50 \mathrm{MW}-\mathrm{sec}$. A fraction of the core was expected to melt.

\section{B. Envelope Extension}

In the early 1970's, the primary experiment sponsor had a need for a larger test space in a flux trap. Safety rods were not installed in all locations and it was concluded that a large facility could be installed if the dummy safety rods were removed. An extensive study was initiated to evaluate the reactor response to the installation of this facility.

Evaluations were performed with one-dimensional and twodimensional neutron diffusion codes. The void worth for partial to total void in radial zones inside of the pressure tube were evaluated with the 1-D diffusion code, SCAMP ${ }^{(4)}$.

The temperature coefficients for the reactor coolant were measured for the various zones in the fuel element in the ATRC. The reactor response to the voiding of the flux trap or various portions thereof was evaluated with the code PARET ${ }^{(5)}$ and system response was then evaluated with an analog simulation.

Sensitivity to uncertainties in the nuclear parameters were

\section{HEATING EVALUATIONS (NON-FISSION)}

Gamma heat rates were measured in the ATRC using thermoluminescent phosphors and in the ATR using ion chambersgraphite-wall and aluminum wall. The uncertainty was estimated to be $-{ }^{+} 20$ percent. These heating rates were used for design of experiments in the irradiation positions until about 1990. evaluated. Typical results are illustrated in Figure 2.

\section{Upgraded Final Safety Analysis}

The evolution of analysis capabilities for evaluation of nuclear reactor safety was incorporated in the ATR. This led to many documents and some techniques or analysis parameters not documented in conformance to evolving requirements. There was an extensive undertaking to verify the safety parameters, and to document the evaluations beginning in the late 1980's.

The fuel element power distributions were evaluated with a three-dimensional simulation utilizing PDQ ${ }^{(6)}$. The sensitivities to experimental loadings, fuel element type, reactor power distribution, and control cylinder position were evaluated. The moderator temperature coefficient was verified with analytical techniques. The reactivity insertions from flux trap voiding in various radial zones were evaluated using SCAMP.

The reactivity insertion from the flux traps was evaluated with RELAP5 ${ }^{(7)}$. Various initiators were evaluated. The results were input to a model of the reactor with 24 channels for computation of the feedback and safety rod insertion. The solution methodology required an interactive solution for the reactor power response. The procedure was to select a reactor power profile, calculate the reactivity insertion, calculate the reactor power response, compare to the assumed profile and repeat until the assumed response was near the calculated response.

The reactor response to a Condition 2 fault is shown in Figure 3.

\section{Process Control Upgrade}

The process control system was upgraded in 1992-1993. There was no longer a need for 9 pressurized water loops and concurrent with the Process Control Upgrade, four flux trap positions were identified for reconfiguration. To preserve the approved safety envelope, it was deemed necessary to closely match the core reactivity and fuel element power distributions. The core physics analysis used the PDQ-7 two-dimensional and three-dimensional fuel core models.

Cross section sets for PDQ-7 were developed using as a basis ENDF/B-V ${ }^{(8)}$ data. The COMBINE ${ }^{(9,10)}$ code was used to generate 31-group cross sections for the SCAMP code. Hafnium cross sections for SCAMP were generated with the 94 group SCRABL ${ }^{(11)}$ code. Diffusion cross sections for PDQ-7 were generated from the SCAMP cross sections using the CMBTPDQ ${ }^{(12)}$ code.

A comparison of the axial profiles for element 25 and 26 is shown in Figure 4.

A large irradiation program to support the development of targets for the High Temperature Gas Reactor-New Production Reactor was started in 1990. The targets were evaluated for neutron and gamma heating using MCNP. A quarter core model was derived from a full-core model of ATR Cycle 73A-2, which was a flux run conducted after a reflector change out. 
Many of the NPR targets were instrumented and temperatures were controlled with a gas mixture to vary the thermal conductivity of a control annulus. The tests also contained helium monitors (HAFM's). This provided opportunity to benchmark the MCNP ${ }^{(13)}$ calculations. The analytical predictions were in excellent agreement with measured results. This method is used for predicting neutron and gamma heat rates in all irradiation experiments at the present time.

\section{HEAT TRANSFER}

The safety of the nuclear test reactor depends on removal of the generated energy from the fuel element to the primary coolant. Two phenomena which can disrupt this cooling process are vapor formation which results in "dryout" or departure from nucleate boiling (DNB) due to high heat flux. The other is a flow excursion due to instability in the coolant channel. This results in DNB also, but the initiator is flow excursion due to vapor formation. The coolant channel geometric parameters determine the exact condition, i.e., beginning of nucleate boiling or saturation at the channel discharge.

\section{A. Design Evaluations - FSAR}

Initial safety evaluations determined the safety margin by using a "hot spot" - "hot channel" methodology. The factors that influence the heat flux at the hot spot were identified and an uncertainty on the determination of the parameter value was predicted. One such parameter was the homogeneity of the fuel loading. The uncertainties were then combined as a product. The nominal peak heat flux multiplied by the product was then required to be less than the DNB heat flux.

The margin to flow instability was maintained in the same manner. The parameters that contributed to the enthalpy rise in the "hot stripe" were identified. The uncertainties were quantified and a product established. The enthalpy rise was then multiplied by the factor and the value had to be less than the allowable, normally the delta in enthalpy required to reach saturation.

An example of the parameters considered and typical values are shown in Table 1, as obtained from Bonilla ${ }^{(14)}$.

The design and initial safety evaluation for heat flux used the "hot spot" - "hot channel" approach. The ATR used a statistical approach based on the error propagation method (F. H. Tingey) ${ }^{(15)}$ for bulk water temperature. The pressure, flow rate, bulk coolant, and wall temperatures were computed using an IBM 7040 program developed for this problem. The results for ATR full power are shown in Table 2.

\section{B. Technical Specifications}

A computer program was written that interfaced with the MITAS $^{(18)}$ thermal analyzer. Later it was revised to interface with the SINDA $^{(19)}$ thermal analyzer. The numerical scheme used for solving the field equations of the fluid flow was that employed by the RELAP5 ${ }^{(20)}$ computer code, written in homogeneous form.

The results from ATR SINDA were used as the boundary conditions for SINDA-SAMPLE which was used to calculate
In the early 1970's the decision was made to convert the FSAR's for the ETR and ATR to a Technical Specification format. A Monte Carlo routine for statistical analysis had just been developed by W. E. Vesely. A simplified approach utilizing this procedure was developed for the ETR. The allowable damage criteria for each category of accident as defined by RDT-C16-1T ${ }^{(16)}$ was developed and acceptable margins defined. For anticipated events the margin was three standard deviations to DNB or flow instability. The unlikely event damage criteria was defined as an energy limit for energy in the fuel plate. The damage criteria was energy deposition required for liquidus and the protective margin was two standard deviations. The extremely unlikely fault damage criteria was chosen as the ignition temperature, or temperature at which the molten aluminum-uranium would burn in a water or steam environment. The protective margin was chosen as three standard deviations.

The conversion to Technical Specifications for the ATR was started near the mid 1970's, as the ETR conversion was being completed. The instrumentation systems were being converted to a plant protective system as defined in RDT C16-1T and design basis analyses were required to support the chosen system, the set points , and to demonstrate the protective margin.

The system response to flow, pressure, reactivity and loss of coolant was evaluated with RELAP4 ${ }^{(17)}$. The Monte Carlo technique was to be applied to ATR as previously done for ETR. However, it was desired to apply the boundary conditions for core differential pressure, reactor power, inlet temperature and pressure from the RELAP4 analyses.

The ability to predict fuel plate behavior under various normal and accident conditions without large conservatism required a threedimensional heat conduction model with hydraulic capability. The required analytical tool needed to accomplish the following:

1. Predict temperature distribution for any one of the 19 fuel plates in an ATR assembly.

2. Model heat transfer processes during forced convection, subcoded transition boiling, subcooled and saturated fully developed boiling, and film boiling regimes.

3. Account for energy required to change material phase.

4. Model steady-state and transient hydraulics for three fuel plate coolant channels.

5. Predict and simulate hydraulic (flow) instability and flow reversal.

thermal-hydraulic statistical margins (standard deviations to CHF, flow instability, fuel plate buckling and aluminum-ignition temperature) along the hot-stripe using the Monte Carlo sampling technique. The SINDA SAMPLE model statistical parameters are listed in Table 3.

\section{Two Primary Pump Operation}

The experimental requirements in the late 1970's resulted in lower power levels in the ATR. This coupled with high electrical 
costs based on peak demand led to safety evaluations to predict the allowable operating conditions with two primary coolant pumps operating instead of three. The limiting faults were evaluated with RELAP5 and ATR-SINDA and SINDA-SAMPLE.

\section{UFSAR}

As discussed in I.C., the thermal-hydraulic analyses were updated during preparation of the UFSAR. The basic methodology using RELAP5, ATR-SINDA, and SINDA-SAMPLE was unchanged. Boundary conditions and damage criteria for the Condition III (Unlikely) faults were revised. The damage criteria for Condition III was changed to a fuel plate temperature limit to maintain fuel plate geometry in a coolable configuration.

\section{SUMMARY}

Safety evaluations have evolved from designs verified by testing to meet the required criteria, with major accidents bounded by conservative assumptions, to analytical modeling techniques that predict plant response to all postulated faults. Large computer codes allow prediction of the consequences for postulated faults. They allow prediction of nuclear characteristics, such as reactivity, photon interaction heating and activation, while others model response to flow, pressure, loss-of-coolant, etc. These simulations are performed on computers kept in an office and in a fraction of the time required only a few years ago. In most cases this has resulted in the ability to operate the test reactors in a more efficient manner, and has allowed the experiment designs to operate closer to desired conditions.

\section{ACKNOWLEDGEMENTS}

Prepared for the U.S. Department of Energy under DOE Idaho Operations Office Contract \#DE-AC07-94ID-13223.

\section{REFERENCES}

1. deBoisblanc, D. R. and S. Cohen, Safety Analysis ReportAdvanced Test Reactor, Volume 2 of 2, IDO-17021, April 1965.

2. Haire, J. C., Subcooled Transient Tests in the Spert-I ReactorExperimental Data, IDO-16342 (July 1958)

3. Dietrich, J. R., Experimental Investigation of the Self-Limitation of Power During Reactivity Transients in a Subcooled, WaterModerated Reactor, AECD-3668 (1954)

4. Beck, C. L., and G. E. Putnam, SCAMP- An Sn Code for Analysis of Multigroup Problems
5. Obenchain, C. F., PARET- A Program for the Analysis of Reactor Transients, IDO-17282 (January 1969)

6. Pfeifer, C. J., PDQ-7 Reference Manual II, WAPD-TM-947, Bettis Atomic Power Laboratory, February 1971

7. Ransom, V. H.,et. al., RELAP5/MOD2 Code Manual, NUREG/CR-4312, U.S. Nuclear Regulatory Commission, Aug 1985

8. Magurno, B. A., R.R. Kinsey, and F.M. Scheffel, Guidebook for the ENDF/B-V Nuclear Data Files, Brookhaven National Laboratory, July 1982

9. Grimesey, R. A.. Et. Al., COMBINE/PC- A Portable ENDF/B Version 5 Neutron Spectrum and Cross Section Generation Program, EGG-2589, EG\&G Idaho, Inc., April 1990

10. Nigg, D.W., Development and Validation NotesCOMBINE/PC, NRRT-N-90-018, EG\&G Idaho, Inc., May 1990

11. Judd, J.L., SCRABL-5 An ENDF/B Version 5 Computer Code for Cross Section Collapsing, EG\&G Idaho, Inc., September 1991

12. Brown, A.W., CMBTPDQ Code Description, Letter to Distribution, Br-05-86, EG\&G Idaho, Inc., September 10, 1986

13. Briesmeister, J.F., ed., MCNP- A General Monte Carlo Code for Neutron and Photon Transport, Version 4.2a, LA-7396-M, CCC-200A, Los Alamos National Laboratory, April 1991

14. Bonilla, Charles F., ed., Nuclear Engineering, McGraw-Hill Book Company, Inc., 1957

15. Tingey, F.H., Error Propagation in Hot Channel - Hot Spot Analysis. IDO-16558 (October 1959)

16. RDT Standard, RDT-C 16-1T, Supplementary Criteria and Requirements for RDT Reactor Plant Protection Systems, Division of Reactor Development and Technology, United States Atomic Energy Commission, December 1969

17. RELAP4/MOD5: A Computer Program for Transient ThermalHydraulic Analysis of Nuclear reactors and Related Systems, Interim Report SRD-113-76, ANC, Idaho National Engineering Laboratory, June 1976

18. Holmstead, G.M., Martin-Marietta Interactive Thermal Analysis System, Version 2.0( Mitas II), Users Manual, EDTM-M-76-2, Martin-Marietta (May 1976)

19. Gaski, J.D., Old/SINDA 1983/ANSI Computer Code, Network Analysis Associates, Inc., (Feb 10,1986)

20. Ransom, HV and J. A. Trapp, RELAP5 Hydrodynamic Model Progress Summary- Pilot Code, PG-R-76-013, Idaho National Engineering Laboratory, Dec 29, 1976 
APPENDIX

FIGURES
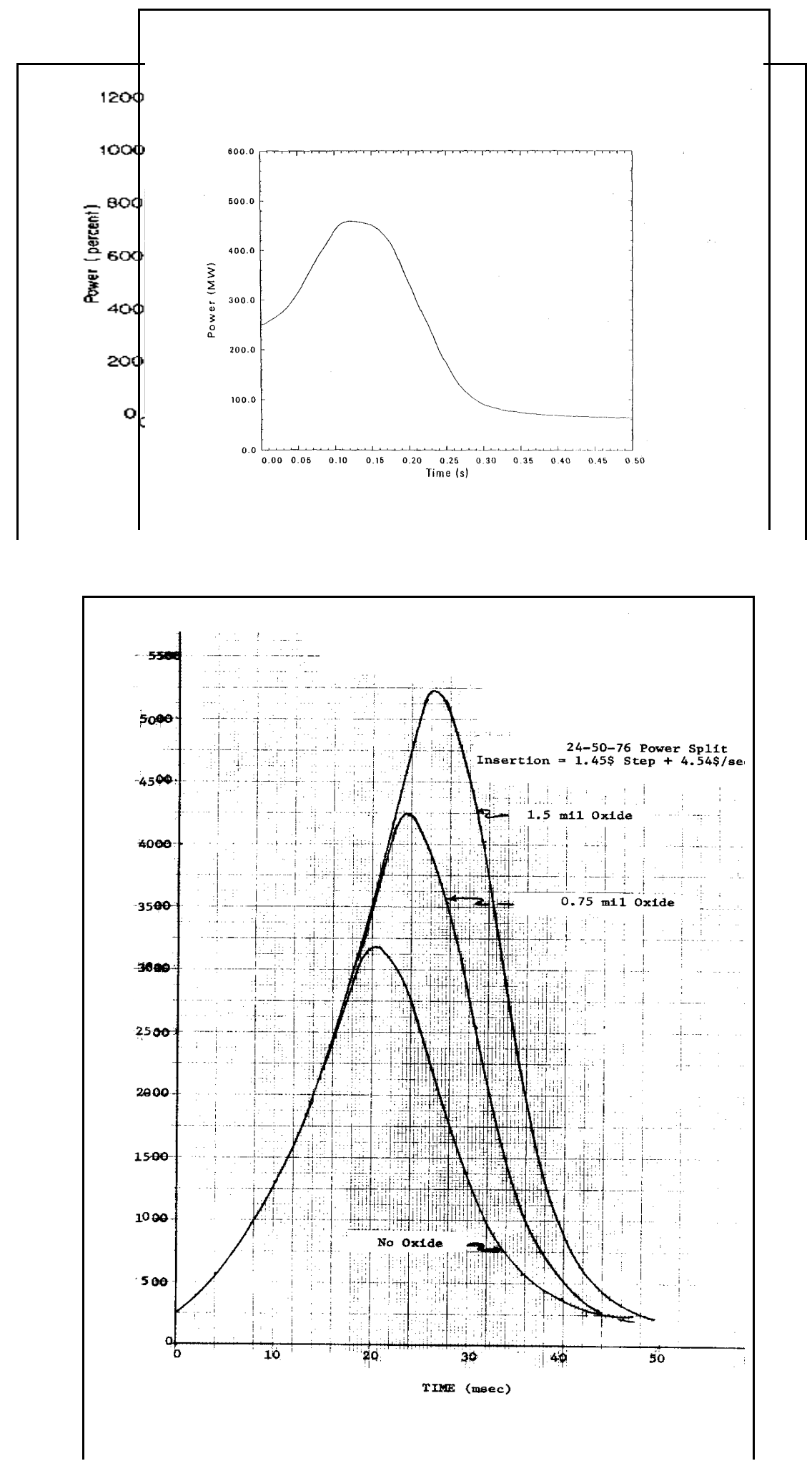


\begin{tabular}{|c|c|c|c|}
\hline Ducertainty in & $\begin{array}{c}\text { Coolane } \\
\text { tempersture' } \\
\text { riae, } \\
1-i_{1}\end{array}$ & $\begin{array}{c}\text { Film } \\
\text { temperature } \\
\text { diffefence, } \\
\text { ol }\end{array}$ & $\begin{array}{c}\text { Fued } \\
\text { temperanzo } \\
\text { differenes, } \\
\Delta !\end{array}$ \\
\hline Xrutron flux.................. & 5.20 & 1.20 & 2.20 \\
\hline 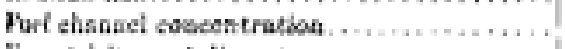 & 2.30 & 1.20 & 1.20 \\
\hline Verrntririty and diameter................ & 2.40 & $12 s$ & 1.10 \\
\hline Flow distribution $., \ldots \ldots, \ldots, \ldots \ldots, \ldots, \ldots$ & $1 . \alpha_{2}$ & 1.02 & \\
\hline 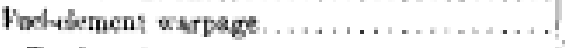 & 1.06 & i. $0 \mathrm{~d}$ & \\
\hline Tutal procuet $\ldots \ldots \ldots \ldots \ldots \ldots \ldots \ldots \ldots$ & 2.95 & 1.90 & 1.60 \\
\hline Fian roeffiriest, $\mathrm{h}, \ldots \ldots \ldots \ldots, \ldots \ldots \ldots \ldots$ & $\ldots \ldots \ldots$ & 1.20 & . \\
\hline hash-eleinebt thermal eonductivity, k....... & $\ldots, \ldots$ & $\ldots \ldots \ldots$ & 1.05 \\
\hline Fut-element thitknets . . . . . . . . . . . ..... & & & 1.05 \\
\hline Total prodact ....................... & $\overline{1.95}=\overline{F_{x}}$ & $2, \overline{28}-\overline{P_{t}}$ & $1.76-P_{0}$ \\
\hline
\end{tabular}

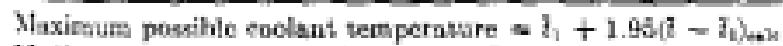

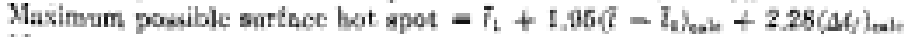

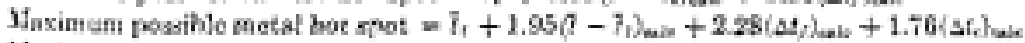

Maxifurum posibile meta! bot spot for Prob. 7-19 (talculatod at $z=+7.5 \mathrm{ft}$

+8. Mclosin, ANL. 5025, 1945 .

$$
-100+1.05 \times 326.4+2.28 \times 115+1.86 \times 28.6=117^{4} \mathrm{~F}
$$

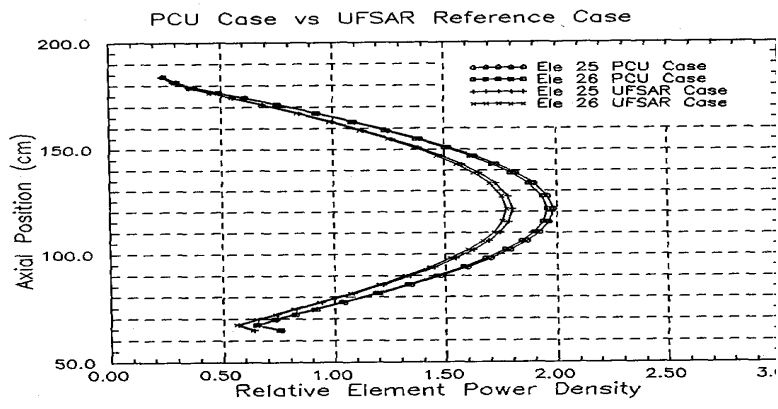




\begin{tabular}{|c|c|c|c|c|}
\hline Parameter & $\begin{array}{l}\text { Mean } \\
\text { Value }\end{array}$ & $\begin{array}{l}90 \% \text { Confidence } \\
\text { Factor }\end{array}$ & $\begin{array}{l}\text { Lower } \\
\text { Limit }\end{array}$ & $\begin{array}{l}\text { Upper } \\
\text { Limit }\end{array}$ \\
\hline 1. Top-of-Core Pressure & $1.0^{\circ}$ & 0.041 & $1 \times 10^{-8}$ & $1 \times 10^{10}$ \\
\hline 2. Core Pressure Drop & 1.0 & 0.041 & $1 \times 10^{-6}$ & $1 \times 10^{10}$ \\
\hline 3. Core Inlet Enthalpy & 1.0 & 0.041 & $1 \times 10^{-6}$ & $1 \times 10^{10}$ \\
\hline $\begin{array}{l}\text { 4. Reactor Power } \\
\text { pre-scram } \\
\text { post-scram }\end{array}$ & $\begin{array}{l}1.0 \\
1.0\end{array}$ & $\begin{array}{l}0.041 \\
0.077\end{array}$ & $\begin{array}{l}1 \times 10^{-8} \\
1 \times 10^{-0}\end{array}$ & $\begin{array}{l}1 \times 10^{10} \\
1 \times 10^{10}\end{array}$ \\
\hline $\begin{array}{l}\text { 5orced Convection } \\
\text { Heat Transfer Coeff. }\end{array}$ & 1.0 & 0.10 & $1 \times 10^{-6}$ & $1 \times 10^{10}$ \\
\hline $\begin{array}{l}\text { 6. Wall Superheat at } \\
\text { Onset of Boiling }\end{array}$ & 1.0 & 0.20 & $1 \times 10^{-8}$ & $1 \times 10^{10}$ \\
\hline $\begin{array}{l}\text { 7. Transition Nucleate } \\
\text { Boiling Heat } \\
\text { Transfer Coeff. }\end{array}$ & 1.0 & 0.10 & $1 \times 10^{-0}$ & $1 \times 10^{10}$ \\
\hline 8. Coolant Velocity & 1.0 & 0.068 & $1 \times 10^{-0}$ & $1 \times 10^{\text {to }}$ \\
\hline $\begin{array}{l}\text { Local Fuel Homogeneity } \\
9 . \text { Axial Levej } 1 \\
10 . \text { Axial Level } 2 \\
11 . \text { Axial Leve1 } 3 \\
12 . \text { Axial Level } 4 \\
13 . \text { Axial Levej } 5 \\
14 . \text { Axial Level } 6 \\
15 . \text { Axial Level } 7 \\
16 . \text { Axial Level } 8 \\
17 . \text { Axial Level } 9\end{array}$ & $\begin{array}{l}1.0 \\
1.0 \\
1.0 \\
1.0 \\
1.0 \\
1.0 \\
1.00 \\
1.0 \\
1.0\end{array}$ & $\begin{array}{l}0.12 \\
0.08 \\
0.08 \\
0.08 \\
0.08 \\
0.08 \\
0.08 \\
0.08 \\
0.12\end{array}$ & $\begin{array}{l}1 \times 0 \\
1 \times 10^{-6} \\
1 \times 10^{-6} \\
1 \times 10^{-6} \\
1 \times 10^{-0} \\
1 \times 10^{-0} \\
1 \times 10^{-6} \\
1 \times 10^{-6} \\
1.0^{\circ}\end{array}$ & $\begin{array}{l}1 \times 10^{10} \\
1 \times 10^{10} \\
1 \times 10^{10} \\
1 \times 10^{10} \\
1 \times 10^{10} \\
1 \times 10^{10} \\
1 \times 10^{10} \\
1 \times 10^{10} \\
1 \times 10^{10}\end{array}$ \\
\hline 18. Low Subcooling CHF & 1.0 & 0.164 & $3 \times 10^{-0}$ & $1 \times 10^{10}$ \\
\hline 19. Fraction of Power & 1.0 & 0.033 & $1 \times 10^{-8}$ & 1.081 \\
\hline 20. Cladding Sol idus & $855 \mathrm{~K}$ & $22.3 \mathrm{~K}$ & $1 \times 10^{-8}$ & $1 \times 10^{10}$ \\
\hline
\end{tabular}




\begin{tabular}{|c|c|c|c|c|c|}
\hline & $\begin{array}{l}\text { Fin Boiling Heas } \\
\text { Tranafer Coeff. }\end{array}$ & 1,0 & 0.20 & $1 \times 10^{\circ}$ & $1 \times 10^{10}$ \\
\hline 37. & Hot Used & - & - & - & - \\
\hline 38. & $\begin{array}{l}\text { Vapor-Wase } \\
\text { Matural Canvection } \\
\text { Vila Bosifng Hest } \\
\text { Transfor Coeff. }\end{array}$ & 1.0 & 0.20 & $1 \times 10^{\circ}$ & $1 \times 10^{10}$ \\
\hline 39. & $\begin{array}{l}\text { Natural Convection } \\
\text { Heat Transfer Coeff. }\end{array}$ & 1.0 & 0.10 & $1 \times 10^{*}$ & $1 \times 10^{17}$ \\
\hline 40. & $\begin{array}{l}\text { Fully Developed } \\
\text { Mucleate doiling } \\
\text { Heat fransfer Coeff. }\end{array}$ & 1.0 & 0.20 & $2 \times 10^{-0}$ & $1 \times 10^{*}$ \\
\hline 41. & High Subcooling cres & 1.0 & 0,164 & $2 x 10^{*}$ & $1 \times 10^{59}$ \\
\hline 42 . & Maturat Convectien CHF & 1.6 & 0.271 & $1 \times 10^{-4}$ & $1 \times 10^{10}$ \\
\hline 43. & $\begin{array}{c}\text { Coelant Channel } \\
\text { Thermal width } \\
\text { Channe1 is } \\
\text { Channel is }\end{array}$ & $\begin{array}{l}1.0 \\
2.0\end{array}$ & $\begin{array}{l}0.057 \\
0.054\end{array}$ & $\begin{array}{l}1 \times 10^{-3} \\
1 \times 10^{4}\end{array}$ & $\begin{array}{l}1 \times 10^{10} \\
1 \times 10^{10}\end{array}$ \\
\hline 44. & Core Outlet Enthalpy & 2.0 & 0.041 & $1 \times 10^{-6}$ & $1 \times 10^{10}$ \\
\hline
\end{tabular}

a. Absolute values of reletive variables are calculated within SIMDA-5AMeLE or abtainsd from ATR-SINOM.

Parameter
21. Cladding Liquidus
Temperature
22. Coolant Channel
Thickness
23. Aluminum-Water
Ignition Temperature
24. Thermal Conductivity
of Corrosion Film
25. Corrosion Film
Thickness
26. Aluminum Density
27. Plate Fueled Length
28. P1ate Half-Thickness
Plate 15
Plate 19
29. UAl, Mass
Plate 15
Plate 19
30. UAl, Density
31. Aluminum Heat of
Fusion
32. UAl Specific Heat
33. Al-606l Specific
34. Hot Spot Peaking
Factor
35. Plate Fueled Width
Plate 15

\begin{tabular}{|c|c|c|c|}
\hline $\begin{array}{l}\text { Mean } \\
\text { Value }\end{array}$ & $\begin{array}{c}90 \% \text { Confidence } \\
\text { Factor }\end{array}$ & $\begin{array}{l}\text { Lower } \\
\text { Limit }\end{array}$ & $\begin{array}{l}\text { Upper } \\
\text { Limit }\end{array}$ \\
\hline $923 \mathrm{~K}$ & $2.8 \mathrm{~K}$ & $1 \times 10^{-6}$ & $1 \times 10^{10}$ \\
\hline 1.0 & 0.0 & $1 \times 10^{-0}$ & $1 \times 10^{10}$ \\
\hline $1444 K$ & 0.0 & $1 \times 10^{-6}$ & $1 \times 10^{10}$ \\
\hline $2.25 \mathrm{~W} / \mathrm{m} \cdot \mathrm{K}$ & $0.574 \mathrm{~W} / \mathrm{m} \cdot \mathrm{K}$ & $1 \times 10^{-6}$ & $1 \times 10^{70}$ \\
\hline $2.54 \times 10^{-5} \mathrm{~m}$ & $5.92 \times 10^{-6} \mathrm{~m}$ & $1 \times 10^{-0}$ & $1 \times 10^{70}$ \\
\hline $2647 \mathrm{~kg} / \mathrm{m}^{3}$ & $43.5 \mathrm{~kg} / \mathrm{m}^{3}$ & $1 \times 10^{-6}$ & $1 \times 10^{10}$ \\
\hline $1.219 \mathrm{~m}$ & $1.905 \times 10^{-2} \mathrm{~m}$ & $1 \times 10^{-8}$ & $1 \times 10^{10}$ \\
\hline $\begin{array}{l}6.35 \times 10^{-4} \mathrm{~m} \\
1.27 \times 10^{-3} \mathrm{~m}\end{array}$ & $\begin{array}{l}2.54 \times 10^{-5} \mathrm{~m} \\
2.54 \times 10^{-5} \mathrm{~m}\end{array}$ & $\begin{array}{l}1 \times 10^{-0} \\
1 \times 10^{-0}\end{array}$ & $\begin{array}{l}1 \times 10^{10} \\
1 \times 10^{10}\end{array}$ \\
\hline $\begin{array}{l}0.1103 \mathrm{~kg} \\
0.0760 \mathrm{~kg}\end{array}$ & $\begin{array}{l}2.16 \times 10^{-3} \mathrm{~kg} \\
1.49 \times 10^{-3} \mathrm{~kg}\end{array}$ & $\begin{array}{l}1 \times 10^{-6} \\
1 \times 10^{-6}\end{array}$ & $\begin{array}{l}1 \times 10^{10} \\
1 \times 10^{10}\end{array}$ \\
\hline $6322 \mathrm{~kg} / \mathrm{m}^{3}$ & $353 \mathrm{~kg} / \mathrm{m}^{3}$ & $1 \times 10^{-0}$ & $1 \times 10^{10}$ \\
\hline $3.97 \times 10^{5} \mathrm{~J} / \mathrm{kg}$ & $6.51 \times 10^{3} \mathrm{~J} / \mathrm{kg}$ & $1 \times 10^{-6}$ & $1 \times 10^{10}$ \\
\hline 1.0 & 0.049 & $1 \times 10^{-6}$ & $1 \times 10^{10}$ \\
\hline 1.0 & 0.049 & $1 \times 10^{-6}$ & $1 \times 10^{10}$ \\
\hline 1.0 & 0.082 & $1 \times 10^{-0}$ & $1 \times 10^{10}$ \\
\hline $\begin{array}{l}8.054 \times 10^{-2} \mathrm{~m} \\
8.618 \times 10^{-2} \mathrm{~m}\end{array}$ & $\begin{array}{l}1.905 \times 10^{-3} \\
1.905 \times 10^{-3}\end{array}$ & $\begin{array}{l}1 \times 10^{-6} \\
1 \times 10^{-6}\end{array}$ & $\begin{array}{l}1 \times 10^{10} \\
1 \times 10^{10}\end{array}$ \\
\hline
\end{tabular}

